\title{
SINTESIS SERBUK NANO TITANIUM DIOKSIDA DAN IDENTIFIKASI STRUKTUR KRISTALNYA
}

\author{
*Vicran Zharvan \\ Universitas Negeri Makassar \\ vicran.zharvan@unm.ac.id \\ Nur Ichzan AS \\ Universitas Muslim Maros \\ nurichzanas@umma.ac.id \\ Rizqa Daniyati \\ Institut Teknologi Sepuluh Nopember \\ rizqa.daniyati@gmail.com \\ Gatut Yudoyono \\ Institut Teknologi Sepuluh Nopember \\ gyudoyono@physics.its.ac.id
}

*koresponden author
Abstrak - Telah dilakukan sintesis serbuk nano titanium dioksida $\left(\mathrm{TiO}_{2}\right)$ dengan menggunakan metode kopresipitasi berbahan dasar titanium klorida $\left(\mathrm{TiCl}_{3}\right)$ serta identifikasi struktur kristal menggunakan perangkat lunak Match!, Rietica dan Origin. Titanium dioksida diperoleh dengan menggunakan bahan dasar titanium klorida $\left(\mathrm{TiCl}_{3}\right)$ yang disintesis menggunakan metode kopresipitasi. Serbuk $\mathrm{TiO}_{2}$ yang diperoleh selanjutnya dikarakterisasi menggunakan metode difraksi sinar-X untuk mengetahui struktur kristal yang terbentuk. Hasil analisis menunjukkan bahwa sampel $\mathrm{TiO}_{2}$ memiliki fase anatase dengan derajat kekristalan sebesar 79.20 persen serta estimasi ukuran kristal sebesar $9.41 \pm 2.13 \mathrm{~nm}$ dengan nilai parameter kisi a $=(3.782907 \pm 0.002221) \AA \hat{A}, \quad \mathrm{~b}=$ $(3.782907 \pm 0.002221) \AA$, $c=(9.478310 \pm 0.005931) \AA ́$.

Kata Kunci : Anatase, Struktur Kristal, Parameter Kisi, $\mathrm{TiO}_{2}$, XRD.

Abstract - Synthesis of nano powder titanium dioxide and its strucure crystal has been obtained. Titanium dioxide was synthesized using titanium chloride $\left(\mathrm{TiCl}_{3}\right)$ as raw material by coprecipitation method. The $\mathrm{TiO}_{2}$ powder then characterized using $x$-ray diffraction to obtain its crystal structure. Analysis results show that the $\mathrm{TiO}_{2}$ powder has an anatase phase with 79.20 percent degree of crystallinity and estimated crystalline size is $9.41 \pm 2.13 \mathrm{~nm}$ with lattice parameters $\mathrm{a}=(3.782907 \pm 0.002221) \AA \hat{\Omega}, \quad \mathrm{b}=(3.782907 \pm 0.002221) \AA$ and $\mathrm{c}=$ $(9.478310 \pm 0.005931) \AA$.

Keywords : Anatase, Crystal Structure, Lattice parameters, $\mathrm{TiO}_{2}, \mathrm{XRD}$ 


\section{A. PENDAHULUAN}

Selama beberapa tahun terakhir ini, material $\mathrm{TiO}_{2}$ telah mendapat perhatian dari beberapa peneliti. Hal ini dikarenakan, material $\mathrm{TiO}_{2}$ merupakan material semikonduktor yang memiliki sifat fotokatalis yang baik (Gupta, Kushwah, Mahobia, Soni, \& Murty, 2019) dan dapat digunakan dalam berbagai aplikasi seperti DSSC (Soni, Murty, Kushwaha, \& Gupta, 2018), penjernih (Haidera, ALAnbarib, Kadhimb, \& Salame, 2017) dan aplikasi nanofluida (Jiang, Li, Yang, \& Du, 2019). Material titanium dioksida memiliki struktur kimia $\mathrm{TiO}_{2}$ merupakan material atau bahan yang bersifat polikristalin. Adapun material $\mathrm{TiO}_{2}$ terdiri atas tiga macam fasa yakni : brokit, anatase dan rutile (Zharvan, Daniyati, AS, Yudoyono, \& Darminto, 2016). Dari ketiga fasa tersebut, anatase merupakan fasa yang stabil dan dapat digunakan dalam berbagai aplikasi seperti aplikasi fotokatalis (Ovenstone \& Yanagisawa, 1999).

Sintesis material $\mathrm{TiO}_{2}$ dapat dilakukan dengan beberapa cara seperti : sol-gel (Vijayalakshmi \& Rajendran, 2012), reaksi pembakaran, hidrotermal (Bilik \& Plesch, 2007) serta kopresipitasi (Zharvan, et al., 2015). Dari berbagai metode tersebut, metode kopresipitasi lebih baik digunakan karena metode ini dapat dilakukan pada temperatur rendah dan metode ini juga memungkinkan untuk mengatur ukuran partikel (Zharvan, et al., 2015) sehingga diharapkan akan diperoleh ukuran partikel $\mathrm{TiO}_{2}$ yang kecil dan homogen. Hasil penelitian menunjukkan bahwa variasi pengadukan memberikan peranan dalam pembentukan fasa $\mathrm{TiO}_{2}$ yakni pada pengadukan 25 jam akan diperoleh dua fasa yakni anatase dan rutil (Molea, Popescu, Rowson, \& Dinescu, 2014) dan fasa rutil diperoleh dengan lama pengadukan 60 jam (Pedraza \& Vasquez, 1999).

Berdasarkan hal tersebut, maka akan disintesis material serbuk $\mathrm{TiO}_{2}$ dengan menggunakan lama wakt pengadukan selama 5 jam. Serbuk $\mathrm{TiO}_{2}$ yang diperoleh selanjutnya akan dikarakterisasi menggunakan metode difraksi sinar-X untuk mengetahui struktur kristal dari serbuk $\mathrm{TiO}_{2}$ yang disintesis dengan menggunakan metode kopresipitasi.

\section{B. METODE}

Sintesis material serbuk $\mathrm{TiO}_{2}$ dilakukan dengan mencampurkan bahan dasar $\mathrm{TiCl}_{3}$ (Merck) dengan konsentrasi $15 \%$ ke dalam air destilasi dan diaduk menggunakan pengaduk magnetik selama 5 jam. Setelah pengadukan, larutan selanjutnya diteteskan dengan larutan $\mathrm{NH}_{4} \mathrm{OH}$ (Aldrich) konsentrasi $28.5 \%$ hingga tercapai tingkat potensial hidrogen sebesar 9. Larutan selanjutnya diaduk hingga terjadi perubahan warna larutan dari ungu ke putih lalu dicuci hingga diperoleh nilai potensial hidrogen 7 kemudian diendapkan selama 24 jam. Endapan yang diperoleh selanjutnya dipanaskan pada temperatur $400^{\circ} \mathrm{C}$ selama 3 jam. Serbuk $\mathrm{TiO}_{2}$ yang diperoleh kemudian digerus hingga homogen lalu dikarakterisasi menggunakan metode difraksi sinar-X (X'Pert MPD, CuK $K_{a}=0.15406 \mathrm{~nm}$ ) pada jangkauan sudut $2 \theta=20^{\circ}-70^{\circ}$. 


\section{HASIL DAN PEMBAHASAN}

Hasil karakterisasi difraksi sinar-X dapat dilihat pada gambar 1 berikut.

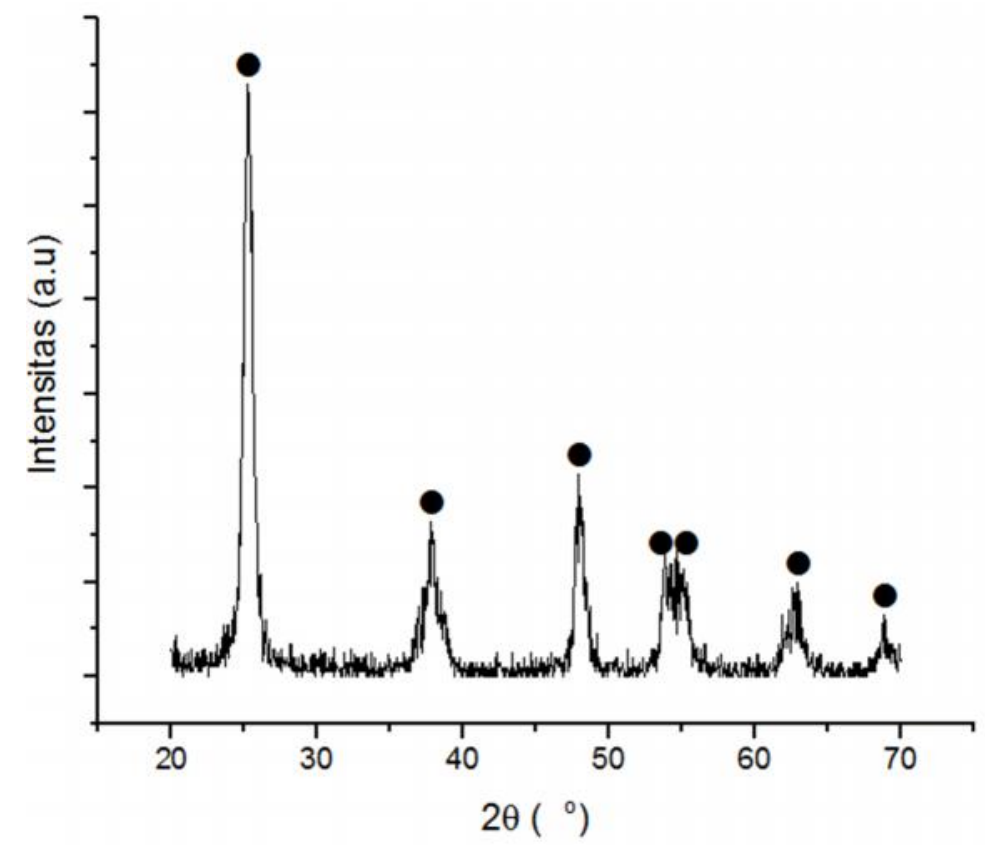

Gambar 1. Data hasil difraksi sinar-X serbuk $\mathrm{TiO}_{2}(\bullet=$ anatase $)$

data difraksi menunjukkan bahwa serbuk $\mathrm{TiO}_{2}$ yang telah disintesis memiliki 7 buah puncak karakteristik dengan puncak dominan pada sudut difraksi $2 \theta=25.2^{\circ}$ yang merupakan puncak karakteristik dari fasa anatase pada $\mathrm{TiO}_{2}$ (Yudoyono, et al., 2016) (Zharvan, Daniyati, AS, Yudoyono, \& Darminto, 2016). Secara lebih lanjut, identifikasi fasa pada serbuk $\mathrm{TiO}_{2}$ yang dapat diperoleh dengan menggunakan perangkat lunak Match! dan Origin. Hasil identifikasi fasa menunjukkan bahwa sampel $\mathrm{TiO}_{2}$ yang diperoleh merupakan material $\mathrm{TiO}_{2}$ berfasa tunggal (single phase) anatase (Horn, Schwerdtfeger, \& Meagher, 1972) sesuai dengan nomor COD (Crystallography Open Database) 5000223 serta diperoleh tingkat kekristalan sebesar 79.20 persen. Berdasarkan hasil yang diperoleh terlihat bahwa fasa tunggal anatase dapat disintesis menggunakan metode kopresipitasi dengan pengadukan selama 5 jam dan serbuk akan memiliki dua fasa yakni anatase dan rutile pada durasi pengadukan 25 jam (Molea, Popescu, Rowson, \& Dinescu, 2014) dan menjadi fasa rutil yang stabil saat dilakukan pengadukan selama 60 jam (Pedraza \& Vasquez, 1999).

Berdasarkan hasil data difraksi sinar-X pada serbuk $\mathrm{TiO}_{2}$ ukuran kristal dapat diperoleh dengan menggunakan persamaan Debye-Scherrer berikut :

$$
D=\frac{0.89 \lambda}{\beta \cos \theta}
$$

di mana $\mathrm{D}$ merupakan ukuran kristal $(\mathrm{nm}), \lambda$ merupakan panjang gelombang sinar-X yang digunakan yakni $0.15406 \mathrm{~nm}, \beta$ merupakan FWHM (radian) dan $\theta$ adalah sudut difraksi (radian) (Sujiono, et al., 2019) yang dapat dilihat pada tabel 1. Berdasarkan tabel 1, terlihat bahwa estimasi ukuran rerata dari 
serbuk $\mathrm{TiO}_{2}$ yang disintesis adalah $9.41 \pm 2.13 \mathrm{~nm}$. Identifikasi lebih lanjut, parameter kisi dari serbuk $\mathrm{TiO}_{2}$ yang disintesis dapat diperoleh dengan menggunakan perangkat lunak Rietica. Perangkat lunak ini bekerja dengan menggunakan metode penghalusan Rietveld (Kisi, 1994) (Sujiono, Said, Dahlan, Imran, \& Samnur, 2018). Hasil analisis Rietveld dapat dilihat pada gambar 2. Terlihat bahwa terdapat kecocokan antara kurva eksperimen (hitam) dan kurva penghalusan (merah) yang menandakan keakuratan dari proses penghalusan yang dilakukan (Sujiono, Said, Dahlan, Imran, \& Samnur, 2018). Selain penilaian secara visual, secara kuantitatif nilai parameter keabsahan dari serbuk $\mathrm{TiO}_{2}$ yang dianalisis memiliki nilai GoF (Godnees of Fit) sebesar 0.97 di mana nilai ini lebih kecil dari 4 yang menandakan bahwa penghalusan dapat diterima (Kisi, 1994).

Tabel 1. Karakteristik struktur kristal serbuk $\mathrm{TiO}_{2}$

\begin{tabular}{|l|ccccccc|}
\hline $2 \theta\left({ }^{\circ}\right)$ & 25.26 & 37.88 & 47.99 & 53.89 & 54.95 & 62.69 & 68.91 \\
FWHM $\left({ }^{\circ}\right)$ & 0.81 & 1.31 & 0.80 & 0.70 & 1.10 & 1.18 & 0.89 \\
Ukuran kristal $(\mathrm{nm})$ & 9.88 & 6.30 & 10.64 & 12.57 & 8.04 & 7.77 & 10.61 \\
Ukuran kristal rerata $(\mathrm{nm})$ & & & $9.41 \pm 2.13$ & & \\
Parameter kisi $(\AA)$ & & $\mathrm{a}=3.782907 \pm 0.002221, \mathrm{~b}=3.782907 \pm 0.002221, \mathrm{c}=9.478310 \pm 0.005931$ \\
\hline
\end{tabular}

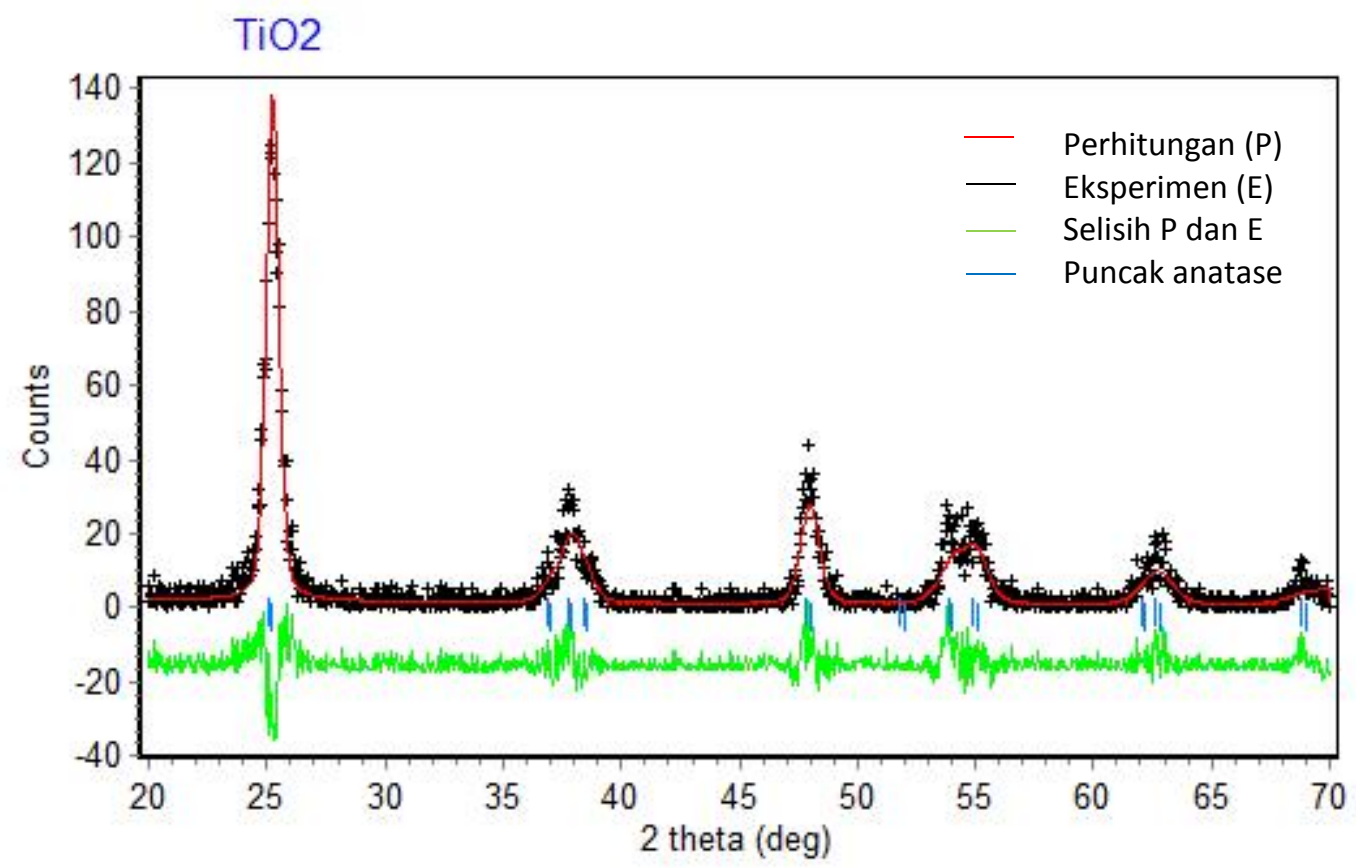

Gambar 2. Hasil penghalusan menggunakan metode Rietveld 


\section{SIMPULAN}

Serbuk nano $\mathrm{TiO}_{2}$ berbahan dasar $\mathrm{TiCl}_{3}$ telah berhasil disintesis dengan menggunakan metode kopresipitasi dengan durasi waktu pengadukan selama 5 jam. Hasil analisis difraksi sinar-X menunjukkan bahwa serbuk nano $\mathrm{TiO}_{2}$ memiliki fasa tunggal anatase dengan tingkat kekristalan sebesar 79.20 persen serta estimasi ukuran kristal sebesar $9.41 \pm 2.13 \mathrm{~nm}$ dengan nilai parameter kisi $\mathrm{a}=$

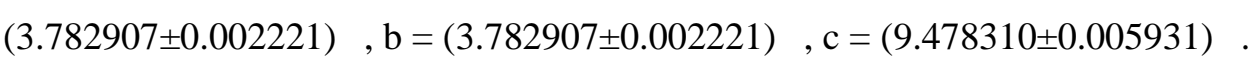

\section{DAFTAR RUJUKAN}

Bilik, P., \& Plesch, G. (2007). Mechanochemical Synthesis of Anatase and Rutile Nanopowders from TiOSO4. Mateials Letter, 1183-1186.

Gupta, A., Kushwah, K. K., Mahobia, S. K., Soni, P., \& Murty, V. V. (2019). Synthesis and Characterization of $\mathrm{TiO} 2$ Nanoparticles for Solar Cell Applications. International Journal of Innovative Technology and Exploring Engineering, 1-4.

Haidera, A., AL-Anbarib, R., Kadhimb, G., \& Salame, C. (2017). Exploring Potential Environmental Applications of TiO2 Nanoparticles . Energy Procedia, 332-345.

Horn, M., Schwerdtfeger, C., \& Meagher, E. (1972). Refinement of The Structure of Anatase at Several Temperatures. Z. Kristallogr, 273-281.

Jiang, W., Li, S., Yang, L., \& Du, K. (2019). Experimental Investigation on Performance of Ammonia Absorption Refrigeration System with TiO2 Nanofluid. International Journal of Refrigeration, 80-88.

Kisi, E. H. (1994). Rietveld Analysis of Powder Diffraction Patterns. Materials Forum, 135-155.

Molea, A., Popescu, V., Rowson, N. A., \& Dinescu, A. M. (2014). Influence of pH on The Formulation of TiO2 Nanocrystalline Powders with High Photocatalytic Activity. Powder Technology, 22-28.

Ovenstone, J., \& Yanagisawa, K. (1999). Effect of Hydrothermal Treatment of Amorphous Titania on The Phase Change from Anatase to Rutile During Calcination. Chemistry of Materials, 27702774 .

Pedraza, F., \& Vasquez, A. (1999). Obtention of TiO2 Rutile at Room Temperature Through Direct Oxidation of TiCl3. Journal of Physics and Chemistry, 445-448.

Soni, P., Murty, V., Kushwaha, K., \& Gupta, A. (2018). A Study of Nature Based Dye with Different Extracting Solvents as a Sensitizer for Dye-Sensitized Solar Cells. Nanoscience Nanoengineering and Applications, 69-73.

Sujiono, E. H., Said, A. C., Dahlan, M. Y., Imran, R. A., \& Samnur, S. (2018). Refinement Analysis Using The Rietveld Method of Nd1.2Fe1O3 Oxide Material Synthesized by Solid-State Reaction. Journal of Nano And Electronic Physics, 1-4. 
Sujiono, E. H., Zharvan, V., Dahlan, M. Y., Said, A. C., Agus, J., \& Samnur. (2019). Study on Morphology and Crystal Structure of Pd Doped Nd1.2FeO3. Materials Today : Proceedings, 258-263.

Vijayalakshmi, R., \& Rajendran, V. (2012). Synthesis and Characterization of Nano-TiO2 Via Different Methods. Archives of Applied Science Research, 1183-1190.

Yudoyono, G., Ichzan, N., Zharvan, V., Daniyati, R., Santoso, H., Indarto, B., . . Darminto. (2016). Effect of Calcination Temperature on The Photocatalytic Activity of TiO2 Powders Prepared by Co-precipitation of TiCl3. AIP Conference Proceedings, 1-7.

Zharvan, V., Daniyati, R., AS, N. I., Yudoyono, G., \& Darminto. (2016). Study on Fabrication of TiO2 Thin Films by Spin-Coating and Their Optical Properties. AIP Conference Proceedings, $1-4$.

Zharvan, V., Daniyati, R., Santoso, H., AS, N. I., Yudoyono, G., \& Darminto. (2015). Fabrikasi Lapisan TiO2 menggunakan Metode Spin-Coating dengan Variasi Pengadukan dan Karakterisasi Sifat Optisnya. Jurnal Fisika dan Aplikasinya, 41-45. 